CHAPTER 4

\title{
Seeing an Eden from a Desert: Topographical Views of Kew and Richmond Gardens in the 1760s
}

\author{
Matthew Storey
}

What can contemporary visual representations of eighteenth-century Kew and Richmond Gardens tell us about what the gardens looked like, the design intentions of the makers, and the experience of the historical visitor? From late 1764 Lancelot 'Capability' Brown re-designed Richmond Gardens, a site directly adjacent to Kew Gardens. In the eighteenth century these two royal gardens had separate and distinct topographies, but now respectively form the western and eastern parts of the Royal Botanic Gardens, Kew. Investigation of a range of visual sources, including maps, topographical prints, and paintings, show not only the physical development of these landscapes, but also how these images were adapted to represent the gardens in specific ways. The changing design and appearance of the gardens reflect the changing debates on garden design, and the rivalries of their makers.

Eighteenth-century landscape gardens can now be experienced at a level of maturity that was never possible when they were first landscaped and planted. As trees have grown and matured, these gardens have taken on an appearance that their creators could only have imagined. However, analysis of topographical views shows the extent to which artists represented these new landscapes as completed visual experiences. The views represent the design intentions of their makers, as much as their actual appearance.

Kew and Richmond Gardens developed and expanded separately from 1718 onwards, when George II and Queen Caroline, when Prince and Princess of Wales, leased Ormonde Lodge, renaming it Richmond Lodge. ${ }^{1}$ Thomas Richardson's 1771 survey, represented in several versions, including a version on vellum from George III's topographical collection now in the British Library, shows the two separate gardens together on the same plan (Figure 4.1). ${ }^{2}$ Most traces of them have now been obscured or obliterated entirely by the later development of the Royal Botanic Gardens, Kew.

Kew Gardens, to the east, had developed since Frederick Prince of Wales leased a house in Kew in 1731, expanding it considerably with the purchase and lease of adjacent land, especially between 1749 and $1750 .^{3}$ The royal association is essential to understand the gardens, with Frederick's widow, Princess Augusta,

\footnotetext{
${ }^{1}$ Desmond, R. (2007). The history of the Royal Botanic Gardens, Kew (2nd edition, p. 4). Royal Botanic Gardens, Kew: Kew Publishing.

2 British Library, shelfmark K.Top.41.16.k.2 TAB.

3 Desmond, R. (2007). Royal Botanic Gardens (p. 24).
}

How to cite this book chapter:

Storey, M. 2020. Seeing an Eden from a Desert: Topographical Views of Kew and Richmond Gardens in the 1760s. In Finch, J. and Woudstra, J. (Eds.), Capability Brown, Royal Gardener: The business of place-making in Northern Europe, pp. 49-59. York: White Rose University Press. DOI: https://doi.org/10.22599/CapabilityBrown.d. CC BY-NC 4.0 


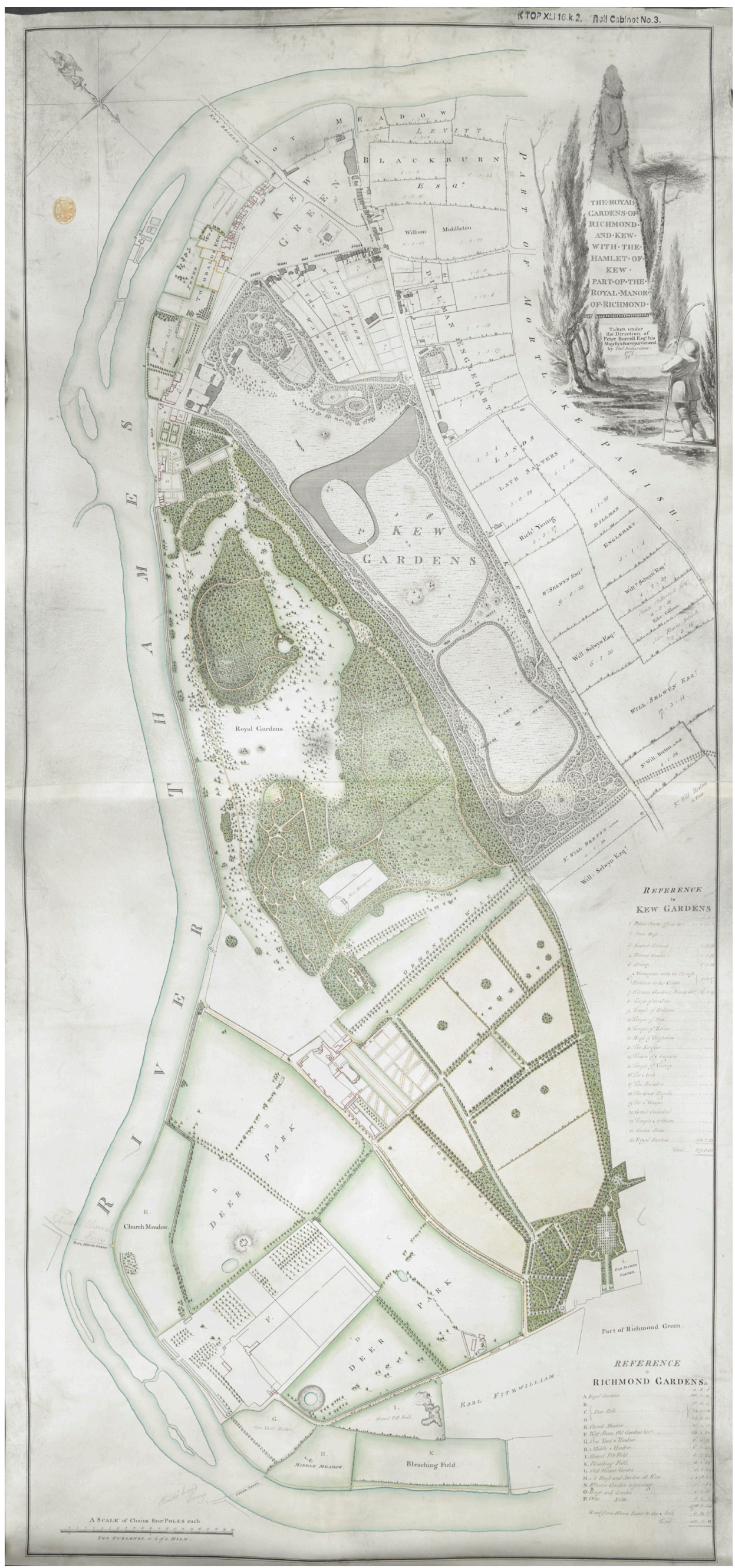

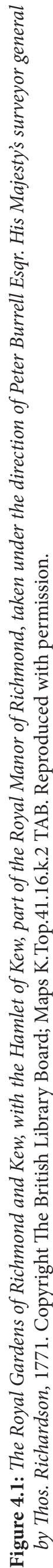


continuing his work after his death in 1751, with the assistance of her close friend and advisor John Stuart, $3^{\text {rd }}$ Earl of Bute, and her son, George III. Between 1757 and 1763 the architect William Chambers designed a series of garden buildings, including the famous pagoda. Kew is best understood as a pleasure garden, with the buildings arranged to give a series of views across the site, enclosed gardens, and buildings along a path. The path wound round a formal lawn in front of the palace, a lake, and two larger meadows.

William Chambers's 1763 publication of his work at Kew, Plans, Elevations and Perspective Views of the Gardens and Buildings at Kew in Surry [sic], includes the following statement about the grounds:

The gardens of Kew are not very large. ... Originally the ground was one continued dead flat: the soil was in general barren, and without either wood or water. With so many disadvantages it was not easy to produce any thing even tolerable in gardening; but princely munificence, guided by a director, equally skilled in cultivating the earth, and in the politer arts, overcame all difficulties. What was once a Desart is now an Eden. ${ }^{4}$

The provider of the princely munificence was Princess Augusta, while the director was Lord Bute. Augusta's son, George III, financed the publication of the volume, while Chambers presented Bute with the manuscript original of it, now in the Metropolitan Museum of Art in New York. The creation of an 'Eden from a desert' was therefore an expression of noble and royal patronage and knowledge, and the associations of royal patronage with a successful landscape are important to understand how the gardens were presented.

The adjacent Richmond Gardens had been landscaped from the 1720s by Charles Bridgeman, for Queen Caroline. From 1729 William Kent was engaged to design a series of garden buildings. The layout of the gardens is recorded in John Rocque's plan, published in Vitruvius Britannicus Volume the Fourth in 1739, while a subsequent version of 1748 shows more of the buildings. The design was determined by the existing field system, with areas of formal wilderness intersected by paths, avenues of trees, and open fields. The garden relied on buildings for interest, and there is a good visual record of the structures designed by Kent, such as the Hermitage or Merlin's cave, from Rocque's plans and other published views. Vitruvius Britannicus Volume the Fourth showed the view of Richmond Lodge from its entrance on the river terrace, and reflects the way many would have experienced the gardens, as the river terrace was an important public route. The design of the garden, with buildings, ponds, and small clearings surrounded by dense planting connected by small paths or avenues of trees, perhaps did not lend itself to wide topographical views within the gardens. Certainly none seem to have survived from this period. Interestingly, none also survive from the later phase of the garden's development when Lancelot 'Capability' Brown worked on them from 1765, with all views focusing on the river. In contrast, Kew Gardens was the subject of several series of topographical images in the 1760s, which in addition to showing how the gardens developed, also show how a single landscape can be perceived and represented in fundamentally different ways.

It has been noted that eighteenth-century landscape gardens are often represented in paintings, prints, or drawings as a series of views, as this reflects their design as a series of impressions. This contrasts with the depiction of earlier formal garden designs, which could be represented in their entirety with an aerial view. ${ }^{5}$ A series of images of a single landscape suggests a narrative of movement and a journey through a space. The images of Kew made in the 1760s consistently suggest narratives of movement, and of how the gardens should be understood, instead of showing how they actually looked.

The problems of using contemporary topographical images to accurately access how the landscape at Kew appeared can be shown by the comparison of two images painted at the same time by the same artist. The Swiss artist Johan Jacob Schalch was commissioned to paint a series of five views of the rapidly developing Kew Gardens by Princess Augusta in 1759. Two paintings, now in the Royal Collection, show a view across the lake to a chinoiserie building known as the House of Confucius. One shows the view by daylight; the other painting shows the same view by moonlight (Figures 4.2 and 4.3). The painting is as much about the dramatic impact of the full moon shining through the clouds and backlighting the scene as it is about what the gardens actually looked like. Closer comparison, including comparing this view to plans of Kew, shows that, although the placement of the features within the landscape is identical and accurate, the trees in the moonlit scene are substantially larger than in the daylight scene. The group of trees behind the bridge in particular is increased in size to create a dark mass to enhance the tonal contrast with the adjacent area depicting the full moon. As the trees obviously did not grow overnight, the accurate depiction of the planting has been subordinated to the demands of the meaning of the image.

\footnotetext{
${ }^{4}$ Chambers, W. (1763). Plans, elevations and perspective views of the gardens and buildings at Kew in Surry (p. 2). London: J Haberkorn.

${ }^{5}$ Remington, V. (2015). Painting paradise: The art of the garden (p. 164). London: Royal Collection Trust.
} 


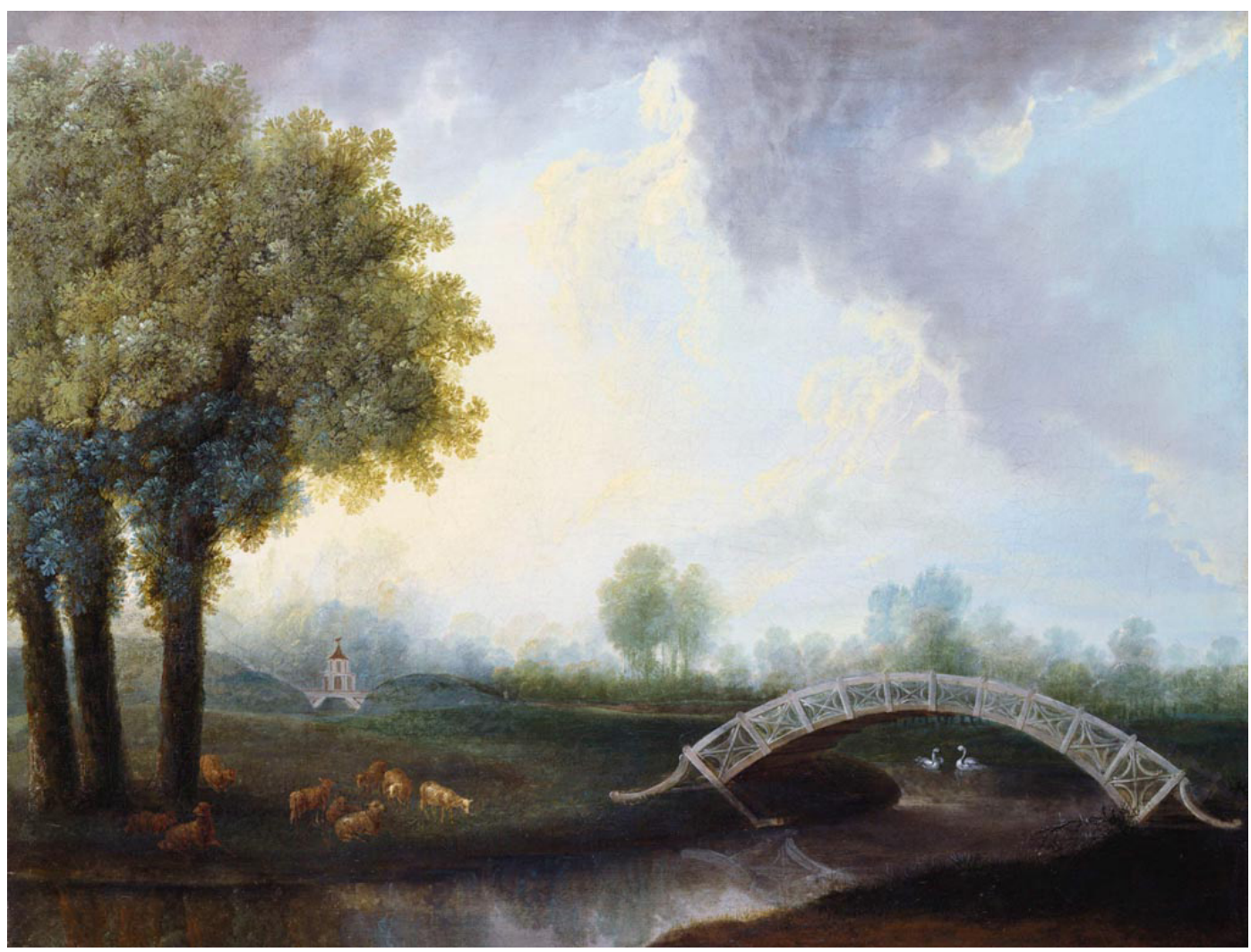

Figure 4.2: The Gardens at Kew, Johan Jacob Schalch c. 1760. Royal Collection Trust / @ Her Majesty Queen Elizabeth II 2019.

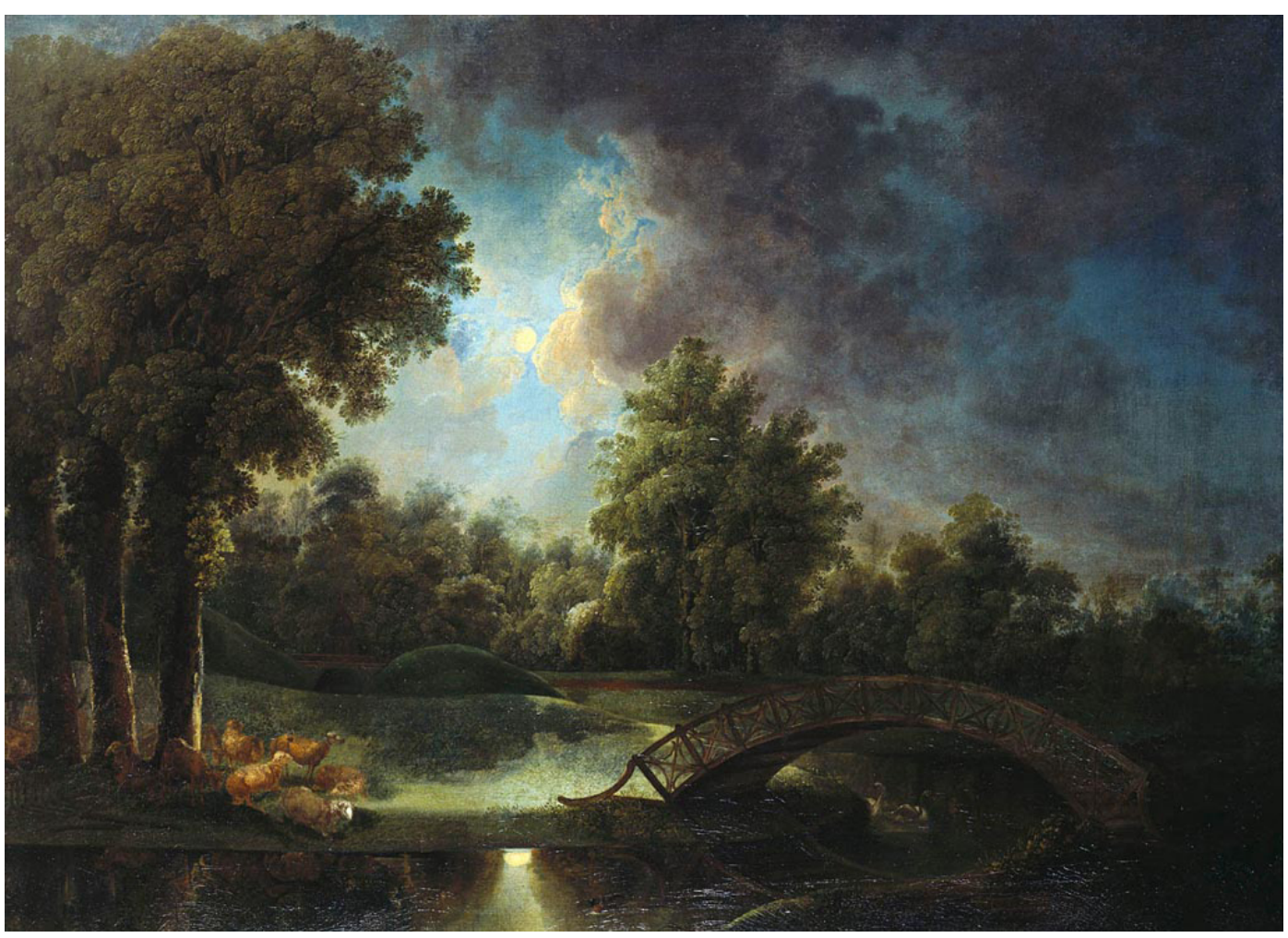

Figure 4.3: The Gardens at Kew by Moonlight, Johan Jacob Schalch c. 1760. Royal Collection Trust / (C Her Majesty Queen Elizabeth II 2019. 
This contrast between the gardens by day and by night also appears in contemporary poetry, which gives an insight into how the gardens were perceived. George Ritso's entirely uncritical poem 'Kew Gardens' from 1763 describes the dawn unveiling the garden. As Ritso describes it:

What Muse is wanting, if Augusta smile?

Soon as Aurora paints the purple Dawn,

And sows with orient Pearl the lucid Lawn;

With new-born Beauties smiles the brightening Sky;

The sick'ning stars retreat; the shadows fly;

the whole Creation as to Life restor'd,

With various Voices praise their common Lord ${ }^{6}$

The Kew revealed by the dawn, and greeted by all creation, is closely linked to Princess Augusta, and her ownership and patronage of the gardens. Elsewhere in the introduction to the poem, and in the poem itself, the virtues of the patron and the garden she created are closely linked. The poem suggests that the meaning of the garden is very different by night and day, with the light of day compared to the enlightened patronage of Augusta.

Schalch is the only artist to depict Kew as a place being created. Other artists show visitors enjoying a finished garden, or shepherds with sheep or groundsmen with scythes working to maintain it. His view The White House, Kew of about 1760 in the Royal Collection shows a labourer with a horse and cart walking past other labourers working on trenches. ${ }^{7}$ As such it is an anomaly in relation to other views, and suggests the garden at this time could be seen as a work in progress, rather than the finished work of the designer and patron.

The difficulties in establishing what images of Kew Gardens are telling us can be explored by analysing a watercolour made by an unknown, and probably amateur, artist in the Royal Collection (Figure 4.4). It shows the view from the mound of the Temple of Victory looking south towards the Ruined Arch, with the Alhambra, Pagoda, and Mosque in the background. Different authors have had different opinions about what this view shows. John Harris writing on William Chambers claimed that it naively shows the gardens with newly planted, immature, trees. Harris comments that it 'was neither engraved nor published - possibly precisely because of the rather awkward appearance of the newly planted trees, which render it of such interest to us.8 Ray Desmond, writing on the history of Kew, claimed that it showed the garden after the early 1780 s, when the ha-ha had been filled in and 'cattle were now confined to the bottom field by an ugly fence.'. The View of the Wilderness with the Alhambra, the Pagoda and the Mosque in Chambers's 1763 publication shows the same ditch further along the garden, appearing shallow and with a fence. This suggests that the fence was already there, and that Harris was correct in supposing that the view reveals the experience of visiting the gardens not reflected in the sophisticated images of professional artists. Plotting this view on contemporary plans of the gardens shows that the foreground of the image was in fact a very small area of ground between the Temple of Victory and the Ruined Arch, which was very sparsely planted with trees in the 1760s.

Despite topographical views which suggest that Kew Gardens was a work in progress in the 1760s, mature elements of the landscape did exist during the major period of development of the late 1750s and early 1760 s. In particular, the gardens incorporated existing trees into the design. Richardson's plan of 1771 shows that elements of the former field system remained in the southern part of the garden. This reflected the way that the garden had been gradually expanded through purchase or lease of adjacent property. The lines of trees along the boundary demarcations of the former fields were partially retained in the unified garden, and would have introduced mature elements into it. Similarly, analysis of a series of plans across the eighteenth century show consistent features across time. A survey of the area made in about 1730, just before it became a royal residence, shows not only the field system, but some of the trees growing at the time..$^{10}$ In particular, three trees are shown growing in the fields. Comparison of the position of these trees with later maps show that these three trees were

${ }^{6}$ Ritso, G. (1763). Kew Gardens: A poem (p. 3). London: M. Lewis.

7 Johan Jacob Schalch (1723-89) The White House, Kew, c. 1760, oil on canvas, The Royal Collection (RCIN 403515).

8 Harris, J. \& Snodin, M. (Eds.) (1996). Sir William Chambers: Architect to George III (p. 64). New Haven and London: Yale University Press in association with The Courtauld Gallery, Courtauld Institute of Art, London.

9 Desmond, R. (2007). Royal Botanic Gardens (p. 75).

10 'A plan or survey of the lands and premises belonging to Nath[anie]ll St. Andre Esqr. and the Rt. Honble the Lady Elizabeth Diana his wife lying at and about Kew in the County of Surrey and let to the Honble [-] Pelham Esqr by the lease annex'd', National Archives, Kew, ref. MF 1/64 and reproduced in Desmond, R. (2007). Royal Botanic Gardens (p. 19). 


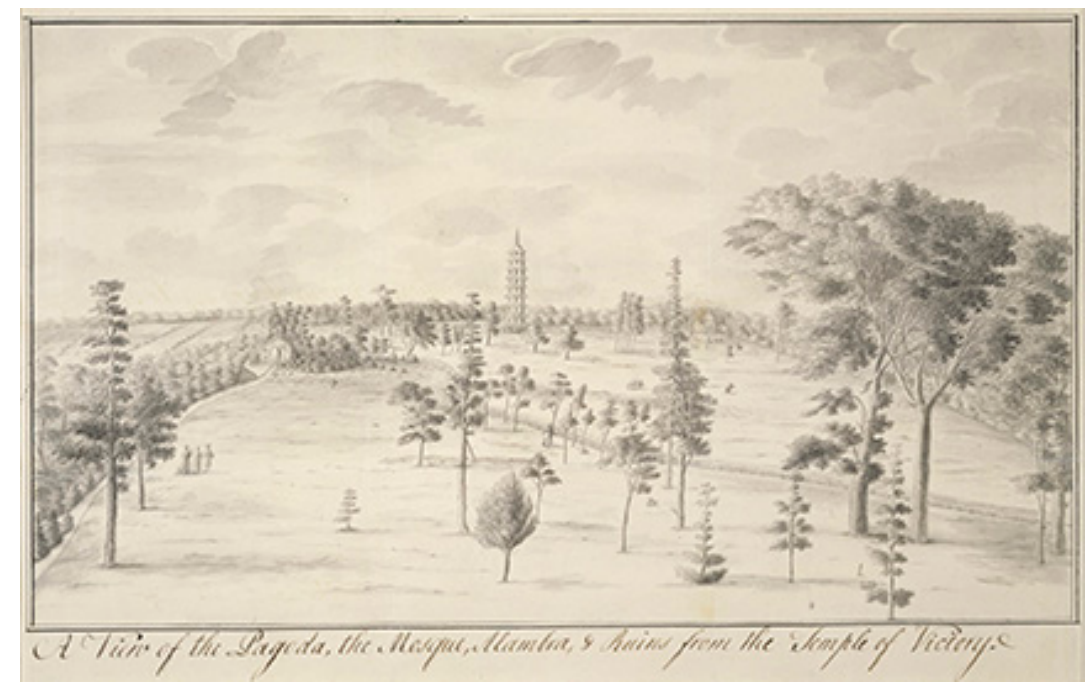

Figure 4.4: A View of the Pagoda, the Mosque, Alambra, \& Ruins from the Temple of Victory [Kew], after? Joshua Kirby. Royal Collection Trust / @ Her Majesty Queen Elizabeth II 2019.

retained as the gardens developed, and are one of the two groups of three trees seen on the island in the lake. The view across the water either to the palace or from the pagoda on the other side, with the trees on the island punctuating the scene, was one of the key views across the gardens. Chambers included the views from both sides of the lake in his 1763 publication.

Chambers's choice of images for his publication was designed to create a series of impressions of the gardens that reflected his involvement in them, and also his own theories of garden design. Chambers's adherence to a style of gardening indebted to the example of William Kent, which he would have been familiar with working at Carlton House, lent itself to representation in a series of views. As John Harris noted, Kew was designed as an 'inward-looking garden' composed around a series of vistas looking across the garden, much like Kent's Carlton House garden. ${ }^{11}$ In his revised 1773 edition of A Dissertation on Oriental Gardening, Chambers expresses his views on gardening through the device of describing Chinese Gardens:

The usual method of distributing Gardens in China, is to contrive a great variety of scenes, to be seen from certain points of view; at which are placed seats or buildings, adapted to the different purposes of mental or sensual enjoyments. The perfection of their Gardens consists in the number and diversity of these scenes; and in the artful combination of their parts; which they endeavour to appear to the best advantage, but also to unite in forming an elegant and striking whole. ${ }^{12}$

The views selected by Chambers, with a combination of long views across the gardens and details showing his architectural contributions, demonstrate that they were deliberately selected to reflect his design ideas through a selection of 'diverse scenes' within an 'elegant and striking whole'. Chambers's Dissertation on Oriental Gardening is not a treatise on gardening but a deliberate attack on Capability Brown and his style of gardening. Chambers describes landscape gardening that too closely resembled nature, by which he certainly means the

${ }^{11}$ Harris, J. (1970). Sir William Chambers: Knight of the Polar Star (Studies in Architecture IX) (p. 35). University Park and London: The Pennsylvania State University Press; Harris, J. \& Snodin, M. (Eds.) (1996). Sir William Chambers (p. 59).

${ }^{12}$ Chambers, W. (1773). A dissertation on oriental gardening (2nd edition, pp. 21-22). London: W. Griffin. 
style practised by Brown and his circle, as 'insipid and vulgar..13 It is tempting to see Chambers's publications as an attempt to spread information about his own work at Kew, as Capability Brown was fast gaining royal favour and about to embark on developing the adjacent Richmond Gardens.

There are problems assessing Brown's work at Richmond, especially as his full plans, made for George III, were not executed. The plan of 1764, now in the archives of the Royal Botanic Gardens, Kew, shows a scheme that would have encompassed Queen Caroline's gardens to the north, with the large area of the old deer park to the south. Two features are worth noting. Firstly, in this plan Brown would have retained a rectangular pond that was part of Caroline's earlier garden, perhaps because of a pragmatic choice to use existing features. Secondly, that the plan is based around a large rectangular space in the area of the existing royal residence of Richmond Lodge, which would have been replaced with a new palace designed by William Chambers. Brown's plans accommodate the palace with a characteristic sense of creating spectacular and memorable settings for houses within landscapes. It is easy to imagine the visual impact of approaching the palace from the north had this scheme been developed. Visitors would have entered the garden and followed a serpentine road, and would have traversed a wooded area before the view of the palace would have dramatically opened up as the trees cleared.

Perhaps because George III was also developing Buckingham House and Windsor, the full scheme was not executed. ${ }^{14}$ The new palace was abandoned after the foundations were begun. Only the north part of Brown's plan, over Caroline's gardens, was developed, and Richardson's 1771 plan, compared with Rocque's view, gives a good indication of its appearance after Brown's work. Although Brown, as we would expect, banished straight lines by suppressing evidence of the older field system, his pragmatism allowed existing elements to remain. In particular, he retained the woodland planted by Bridgeman, which would have been maturing, and the paths within it. Brown worked to vary the much-commented-on flatness of the site by excavating a depression at the north-east of the site in 1773, which modern-day visitors to Kew will now know as the Rhododendron Dell. Most significantly, Brown removed the river terrace constructed by Caroline, after an Act of Parliament of 1766 allowed George III to close the road, providing a towpath was maintained. ${ }^{15}$ This allowed Brown, with the aid of a ha-ha, to connect the gardens with the river. This area, where the gardens meet the river, is the only part of Brown's work at Richmond to have been recorded in topographical views, with J. J. Boydell publishing an aquatint after J. Farington in his History of the Principal Rivers of Great Britain, Vol. 2, in 1796. Significantly, it is the view across the river to Syon House, within its own Capability Brown-designed landscape, that is recorded. This is frustrating if we want to understand what Brown's work looked like, but indicative of what was valued in the gardens, and of the limitations of taste in eighteenth-century view-making.

Chris Sumner and Susan Darling have written on the relationship between Richmond and Syon, with the changes to the terrace enabling two modern landscapes to be seen either side of the river. ${ }^{16}$ George III himself had emphasised this relationship in a drawing dated to before Brown's work, now in the Royal Collection (Figure 4.5). Syon House is viewed across the river, through mature trees. Taking the angle at which Syon House is seen as a guide, it appears that the view is taken from within the deer park south of the formal part of Richmond Gardens, but very near to the divide between them. The drawing is often dated to about 1760 . Views of designed landscapes at this time are usually, if not always, centred on a house or built feature. This conformed both to the desire of a patron to have his house depicted to show wealth, but also because an appreciation of wild landscapes without the influence of man had yet to be widely accepted.

John Spyers provides one of the few such views of a Capability Brown landscape amongst his 1786 watercolours of Fisherwick (Staffs). Brown's employee placed the house at the centre of his images, apart from one, of the north and east fronts of Fisherwick, where the house is shown to the side to allow a curved stretch of water to occupy the foreground. Similarly, when Richard Wilson painted Croome Court (Worcs) in about 1758-59, a house and landscape designed by Brown in the 1750s, he depicted the house across the gently curved water, with figures in the foreground. ${ }^{17}$ There is a compositional similarity to Wilson's views of Syon from Richmond Gardens. Existing in three versions - two day views, and one by evening light - these paintings are dated to the

${ }^{13}$ Chambers, W. (1773). Dissertation (pp. viii-ix).

${ }_{14}$ Desmond, R. (2007). Royal Botanic Gardens (pp. 68-69).

${ }^{15}$ Desmond, R. (2007). Royal Botanic Gardens (p. 67).

${ }^{16}$ Sumner, C. (2016). A river runs through: Lancelot 'Capability' Brown at Syon and Kew. London Landscapes - Newsletter of London's Parks and Gardens [Trust], 42(Spring 2016), 18-23 (p. 22).

17 Richard Wilson (1713/14-82), Croome Court, Worcestershire, 1758-59, oil on canvas, Richard Wilson Online reference P83. Available at http://www.richardwilsononline.ac.uk, accessed 9 November 2016. 


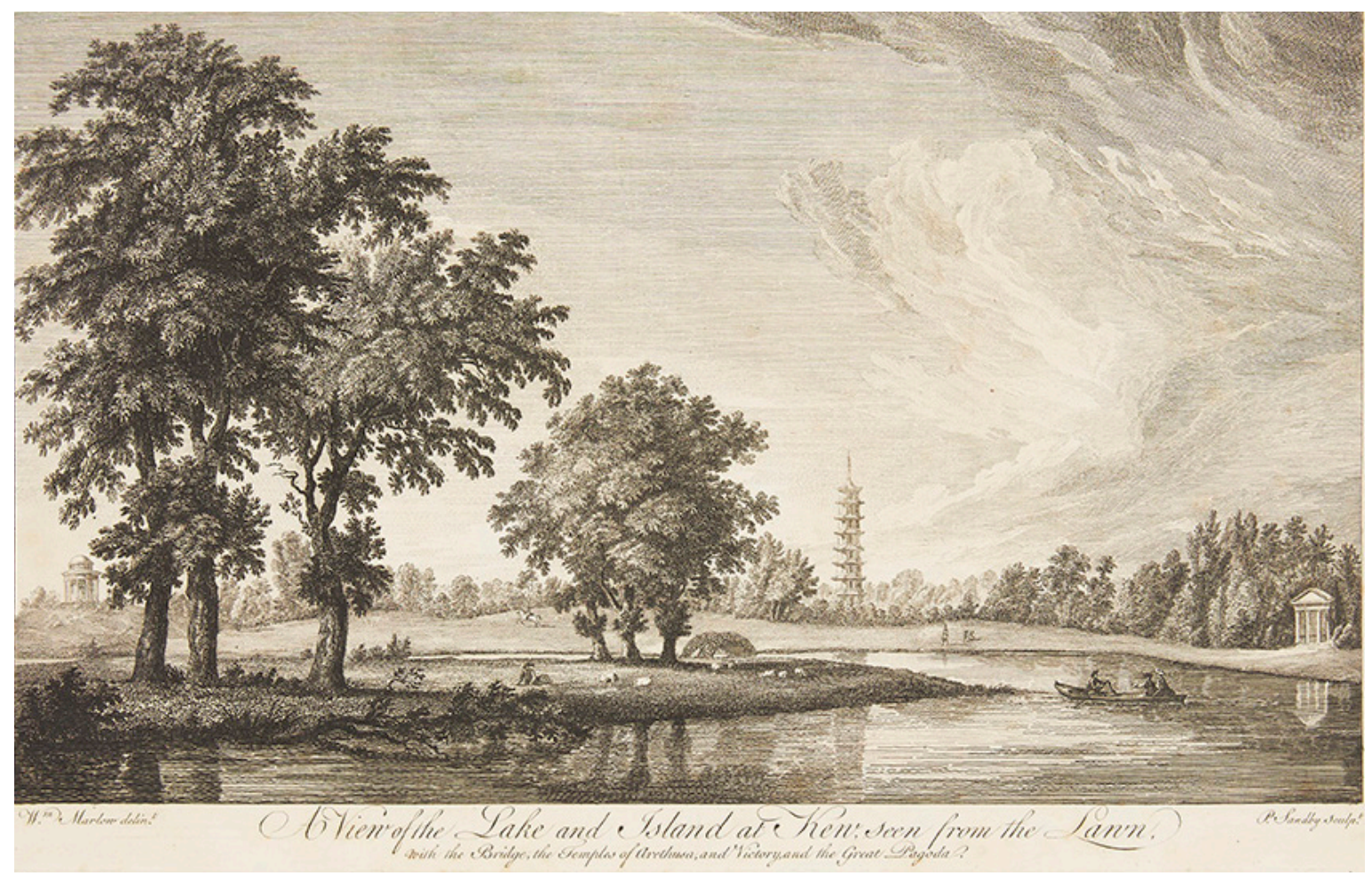

Figure 4.6: A View of the Lake and Island at Kew, seen from the Lawn with the Bridge, the Temples of Arethusa and Victory and the Great Pagoda, Paul Sandby after William Marlow. From the book Plans, Elevations, Sections and Perspective Views of the Gardens and Buildings at Kew in Surry, by Sir William Chambers, 1763. (c) Historic Royal Palaces.

his intervention in this part of the landscape at Kew was mocked in 1774, when 'On GARDENS and the FALSE TASTE thereof particularly of KEW and RICHMOND' appeared in The London Magazine:

Richmond gardens now declare the hand that spoilt them; nor is there a person who can recollect the beauty of the lengthened terrace but censures the innovator - Mr. Capability Brown. ${ }^{20}$

In the same piece the author praises aspects of Kew Gardens, closely associating them with their royal creators, with a crude innuendo at Lord Bute's expense. It was widely suggested that the widowed Princess Augusta and Lord Bute's relationship was sexual:

The exotic ground in Kew gardens is the only princely thing about this country. It was established at the expence of his majesty's mother and is the only remaining memorandum to her memory except the erection of Lord Bute called the Chinese Pagoda. The first is visited by all men of taste the last is equally beheld by the prince and the fool.

The only beauty of this garden is the first view of the lawn with the Pagoda at the end which though the termination hath not the effect of conclusion, (for the hill of Richmond is seen to rise gradually and nobly behind it) gives a dignity and an extent to the gardens very unexpected. The trees in general are beautiful and seem to rejoice in the soil..$^{21}$

Two images of this celebrated view in Kew Gardens made in the 1760s underline how seductive, but unreliable, views can be when attempting to establish what gardens looked like, instead of how they were understood. Paul Sandby's print after a watercolour by William Marlow was produced to illustrate William Chambers's 1763 publication (Figure 4.6), a book about the architecture and design of the gardens.

${ }^{20}$ The London Magazine, August 1774, p. 360.

${ }^{21}$ The London Magazine, August 1774, pp. 359-360. 


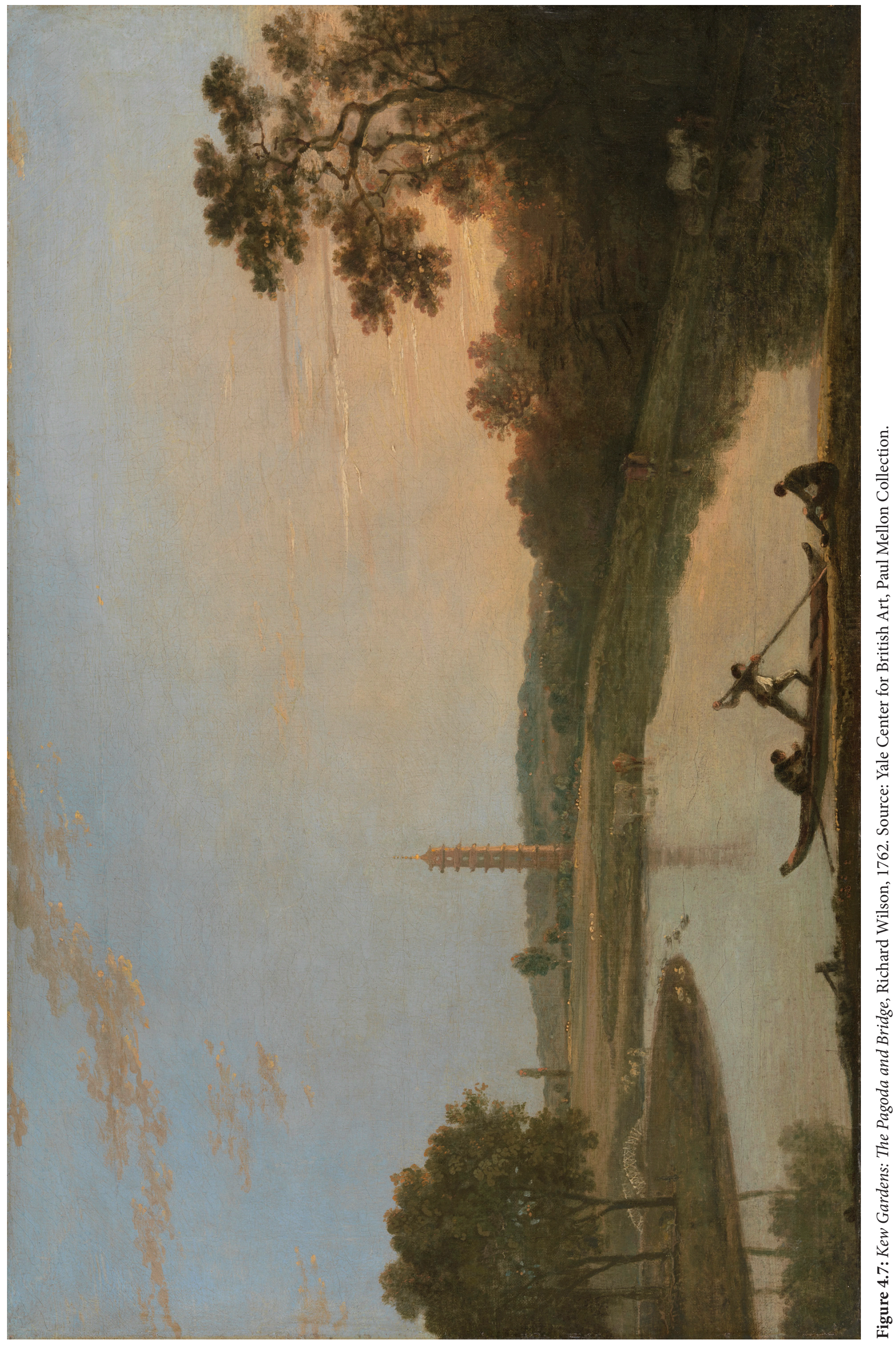


Unusually, Marlow's preparatory sketch survives in the British Museum. Comparing this view to the finished watercolour and to the print made after it shows that Marlow deliberately cleaned up and altered the image. Two small huts visible on the island were removed in the finished image to present an idealised view of the gardens. Similarly, the Temple of Victory was brought into the right-hand side of the image, and the spatial relationships between the temples, trees, and distant pagoda were modified to suit the proportions of the image.

Richard Wilson had depicted the garden from the same viewpoint in about 1761-62 (Figure 4.7). The scene is suffused with an evening sunlight, although, as often seen in Wilson's works, it seems to have more in common with the sun of the Roman campagna than of Surrey. Comparing Wilson's painting with Sandby and Marlow's published views, inconsistencies between the two images emerge. More of the surface of the island and the far bank are visible, suggesting Wilson's view is painted from a higher vantage point. This is also indicated by the relationship between the trees on the island and the pagoda, with the pagoda appearing on a level with the trees in Wilson's view but below the level of the trees in Sandy and Marlow's image. This makes the pagoda appear larger than it should from this position, and again suggests that Wilson's view seems to be taken from a high vantage point. As Marlow's sketch was probably made on the spot, his view is more likely to be accurate. Considering how flat the land was in this part of the gardens, and indeed across the gardens as a whole, Wilson's view must build in artistic licence. Wilson's figures also appear disproportionately large in the foreground. However, both images use manipulations to achieve an idealised view of the gardens. As with all views of Richmond and Kew Gardens which modify the gardens, each in their way convey and render permanent Chambers's statement about the gardens that, with royal taste and patronage, 'What was once a Desart is now an Eden.'22

Views made by artists of the gardens and written opinions expressed in the press and publications defined the experience of these gardens for people who had not visited them. They form an essential source for the modern historian, especially where original topographies and plantings are lost. Rivalries were viciously played out in these media. Chambers's A Dissertation on Oriental Gardening was quickly satirised by William Mason's An Heroic Epistle to Sir William Chambers. At first published anonymously, some thought Brown was the author. When a visitor, Colonel Barré, saw the book in Brown's house, assuming this proved his host's authorship, he declared 'This is too much! - too much indeed!', requiring Brown to reply 'Upon my honour, Sir, I did not write it. ${ }^{23}$ With Chambers, Brown and their contemporaries seeking limited royal and architectural patronage, style, and the dissemination of it through visual and textual media, was an important way of playing out their commercial rivalry.

\section{Select Bibliography}

A select bibliography is available at the end of this volume, or at: https://doi.org/10.22599/CapabilityBrown.o.

\footnotetext{
${ }^{22}$ Chambers, W. (1763). Plans, Elevations and Perspective Views (p. 2).

${ }^{23}$ Stroud, D. (1950). Capability Brown (p. 153).
} 